\title{
Occurrence and distribution of diverse populations of magnetic protists in a chemically stratified coastal salt pond
}

\author{
Dennis A. Bazylinski ${ }^{\text {a }}$, David R. Schlezinger ${ }^{\mathrm{b}}$, Brian H. Howes ${ }^{\mathrm{b}}$, \\ Richard B. Frankel $^{\mathrm{c}}$, Slava S. Epstein ${ }^{\mathrm{d}}$ \\ a Department of Microbiology, Iowa State University, 207 Science I, Ames, IA 50011, USA \\ ${ }^{\mathrm{b}}$ Marine Sciences Center, University of Massachusetts at Dartmouth, 706 South Rodney French Boulevard, New Bedford, \\ MA 02744-1221, USA \\ ${ }^{c}$ Department of Physics, California Polytechnic State University, San Luis Obispo, CA 93407, USA \\ d Department of Biology, Marine Science Center, Northeastern University, East Point, Nahant, MA 01908, USA
}

\begin{abstract}
Chemical stratification occurs in the water columns and sediments of many aquatic habitats resulting in vertical chemical and redox gradients. Various types of microorganisms are often associated with specific depths and chemical parameters in these situations. For example, magnetite-producing magnetotactic bacteria are known to form horizontal "plates" of cells at the oxic/anoxic transition zone (OATZ) of such environments. Here, we report the presence of populations of diverse magnetic protists in a seasonally chemically stratified, coastal salt pond. The protistan types included several biflagellates, a dinoflagellate, and a ciliate that were each associated with specific depths and thus, specific chemical, microbiological and redox conditions in the water column. Most cells contained crystals of magnetite usually arranged in chains similar to the magnetosomes in the magnetotactic bacteria. The origin of the particles is unknown. There was no evidence of the presence of endosymbiotic magnetotactic bacteria within the protists nor were the protists observed to be engulfing magnetotactic bacteria despite the fact that high numbers of the latter were present at the same depths as the protists. However, this does not exclude ingestion of magnetotactic bacteria as a source of the magnetic particles while others may biomineralize magnetite. Because protists play an important role in the availability of iron for phytoplankton in marine waters by ingesting and reducing colloidal iron particles, the protists described here could play a significant role in iron cycling in chemically stratified anoxic basins, either through endogenous production of magnetic iron oxide and/or iron sulfide particles, or by ingestion of magnetotactic bacteria and the subsequent reduction and dissolution of iron oxide and/or sulfide particles in their magnetosomes.
\end{abstract}

Keywords: Magnetic protists; Coastal salt pond; Chemically stratified

\section{Introduction}

Magnetotactic bacteria biomineralize intracellular, membrane-bounded, single-domain magnetic particles of the iron oxide, magnetite $\left(\mathrm{Fe}_{3} \mathrm{O}_{4}\right)$, or / and the 
iron sulfide, greigite $\left(\mathrm{Fe}_{3} \mathrm{~S}_{4}\right)$ (Bazylinski and Moskowitz, 1997). These particles, called magnetosomes (Balkwill et al., 1980), impart a permanent magnetic dipole moment to the cell causing it to passively align along the Earth's geomagnetic field lines as it swims (Frankel and Blakemore, 1980). This phenomenon, termed magnetotaxis (Blakemore, 1975), is thought to aid the bacterial cell in locating and maintaining an optimal position in vertical chemical and redox gradients (e.g., oxygen) in stratified water columns and sediments by reducing a three-dimensional search problem to a one-dimensional search problem (Frankel et al., 1997).

In addition to procaryotes, a number of higher organisms are also known to contain and likely biomineralize single-magnetic-domain particles of magnetite including fish, birds, and humans (Kobayashi and Kirschvink, 1995). There has only been a single report of a magnetic response and magnetite particles in a single-celled eucaryote, a Euglenoid alga (Torres de Araujo et al., 1985). Here, we report magnetic responses and magnetite particles in diverse types of protists associated with specific depths and chemical parameters in a seasonally, chemically stratified coastal salt pond and the possible roles of these organisms in the biomineralization, dissemination and dissolution of magnetosomes and in iron cycling in general.

\section{Materials and methods}

\subsection{Study site and sampling procedures}

Salt Pond is a well-characterized, shallow (ca. 5.5-m depth) eutrophic marine basin on Cape Cod, MA, USA, with a significant freshwater input that results in a density stratification (Wakeham et al., 1984, 1987). While aerobic processes dominate the epilimnion, the anaerobic hypolimnion or anoxic zone contains high concentrations of hydrogen sulfide (up to $5 \mathrm{mM}$ ) generated from bacterial sulfate reduction. In summer, the anoxic zone rises to within 2-3 m of the surface and the oxic-anoxic interface (oxic/anoxic transition zone, OATZ) becomes quite pronounced with steep opposing oxygen and hydrogen sulfide gradients. A dense "plate" of microorganisms exists at the OATZ and the top of the hypolimnion in the anoxic zone where hydrogen sulfide first becomes detectable. Water samples were collected from discreet depths using a peristaltic pump as previously described (Wakeham et al., 1987), stored in 1- to 2-1 plastic or glass jars and brought back to the lab within $1 \mathrm{~h}$ of collection for examination for the presence of magnetotactic microorganisms.

\subsection{Chemical analyses}

Immediately prior to sampling, duplicate CTD casts were performed which provided fine-scale temperature and salinity profiles. Dissolved oxygen was determined using a self-stirring Orbisphere model 27141 dissolved oxygen meter equipped with a sulfide-insensitive electrode. All dissolved oxygen values were corrected for salinity and temperature. Water samples for sulfide and iron measurements were collected in-line by syringe to prevent oxidation, i.e., samples for sulfide measurements were withdrawn directly from the stream of water passing within the tubing with syringes that already contained reagents without air bubbles while those for iron determinations were purged several times with water before taking the final sample and did not contain reagents. Syringes were then plunged into butyl rubber stoppers. Sulfide was determined by the method of Cline (1969). Iron species were measured by the method of Lovley and Phillips (1987), modified by increasing the ferrozine concentration to $10 \mathrm{~g} / 1$. Samples (10 $\mathrm{ml})$ were added to borosilicate test tubes containing either $1 \mathrm{ml}$ ferrozine reagent (soluble $\mathrm{Fe}^{2+}$ ), $1 \mathrm{ml}$ ferrozine reagent and $1 \mathrm{ml}$ of $0.05 \mathrm{M}$ hydroxylamine $\cdot \mathrm{HCl}$ (total $\mathrm{Fe}$ ), or $1 \mathrm{ml}$ ferrozine reagent and $1 \mathrm{ml}$ of $0.1 \mathrm{M} \mathrm{HCl}$ (total $\mathrm{Fe}^{2+}$ ). Water was added with the syringe tip within the reagent to prevent oxidation during transfer. Sulfide and iron assays were performed in triplicate for each depth.

\subsection{Collection of magnetotactic microorganisms}

Magnetotactic microorganisms were collected from sample bottles by placing the south pole of a bar magnet adjacent to the jar about 2 to 3 in. from the bottom. After about $0.5 \mathrm{~h}$, water from the point in the jar closest to the magnet was collected with a Pasteur pipette, which was laid horizontally on a lab 
bench. The south pole of a bar magnet was then placed about $1 \mathrm{~cm}$ from the thin opening of the pipette. After about 15-20 min, drops of water from the pipette tip were deposited on microscope slides and form-var coated electron microscopy grids for optical and electron microscopy, respectively. The magnetic and magnetotactic responses of microorganisms in water drops were determined with a small, permanent magnet on the optical microscope stage and recorded with a video camera and recorder and photographed with a color video printer (Sony model UP 5600MD; Sony Electronics, San Jose, CA). The magnet produced a field of several gauss across the drop.

\subsection{Electron microscopy}

Microorganisms were viewed using a Zeiss (Carl Zeiss, Thornwood, NY) model 10CA transmission electron microscope (TEM) operating at $80 \mathrm{kV}$. Analytical electron microscopy was performed on cells and magnetosomes using a VG Microscopes (Fisons Instrument Surface Systems, East Grinstead, UK) model HB-603 scanning transmission electron microscope (STEM) operating at $180 \mathrm{kV}$ linked to a field-emission electron gun and a Link (Link Analytical, Gif Sur Yvette, France) EDS system capable of generating elemental maps of samples similar to systems described previously (Bazylinski et al., 1994).

\section{Results}

\subsection{Chemical parameters and stratification}

During July 1995, we sampled and measured specific chemical parameters of discreet water depths of Salt Pond as part of our on-going study of magnetotactic bacterial populations at the site. Chemical parameters from the July 1995 sampling date are shown in Fig. 1. The OATZ extended from about 3.3 to $3.7 \mathrm{~m}$ at which point hydrogen sulfide became detectable (Fig. 1). This zone was also associated with the highest concentrations of dissolved $\mathrm{Fe}^{2+}$ and total Fe suggesting that iron reduction is a significant biogeochemical process at the OATZ in
Salt Pond. Repeated studies during several summers prior to and following 1995 showed that the stratification pattern shown in Fig. 1 occurs on a yearly basis with only slight changes usually in the relative depth of the OATZ.

\subsection{Magnetotactic bacteria and protists}

During the sampling period of July 1995, magnetotactic bacteria were found at all depths below $3 \mathrm{~m}$ as expected. At least five morphologically distinct types were present with the presence and relative concentration of each type strongly dependent on depth, i.e., chemical and/or redox parameters. A more detailed report of these organisms, as well as the chemical and nutrient parameters of Salt Pond, is in progress (Bazylinski, D.A., Schlezinger, D.R., Howes, B.L, Moskowitz, B.M., Frankel, R.B., manuscript in preparation). In addition to the bacteria, a number of morphologically distinct, magnetically responsive protists were also found below $3 \mathrm{~m}$, with morphological types and relative concentrations of those types also dependent upon water depth. The magnetic protistan types included several types including several flagellates, biflagellates, dinoflagellates and a ciliate. The dimensions of these organisms were typical of eucaryotes rather than procaryotes and ranged from $3.8 \times 9.3$ to $15 \times 28 \mu \mathrm{m}$. All types had clearly identifiable eucaryotic structures including nuclei and eucaryotic (based on size) flagella and cilia.

Most of the protists were extremely fragile and difficult to collect in enough numbers making samples for microscopy and analysis virtually impossible. However, four types of protists, shown in Fig. 2, could be collected for microscopy and analysis. These included a dinoflagellate, designated organism ' $a$ "; two different biflagellates, " $b$ " and " $c$ "; and a ciliate, "d". Some characteristics of these protists and the depths at which they were collected are shown in Table 1. Specific identification of the protists is tentative (Table 1). However, protist " $a$ ", clearly belongs to the phylum Dinoflagellata based on morphological characteristics. The biflagellates " $b$ " and "c" appear to belong to the phylum Cryptophyta, " $\mathrm{b}$ " resembling several species of Chilomonas. Ciliate " $\mathrm{d}$ " is clearly a Cyclidium 


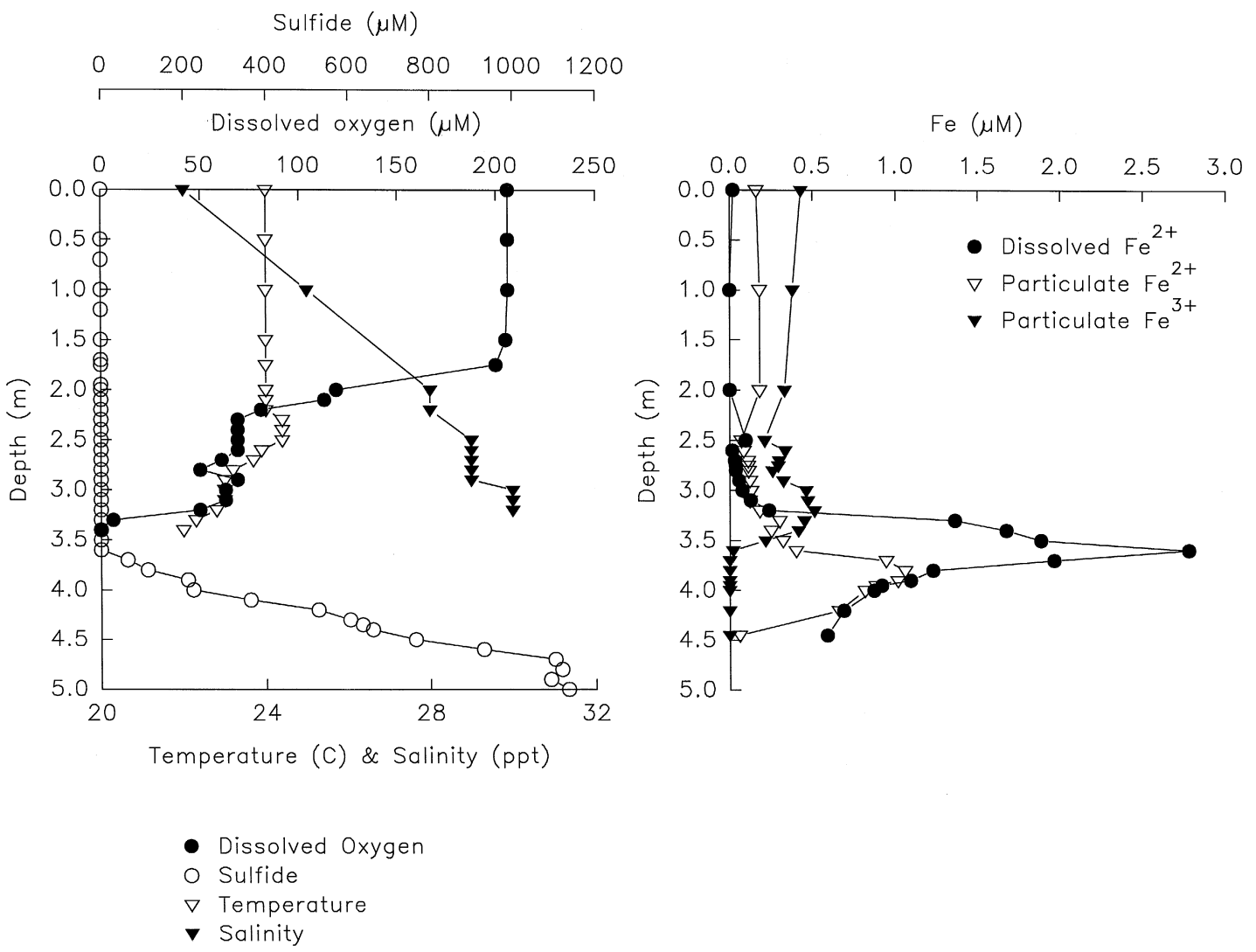

Fig. 1. Chemical depth profiles of Salt Pond measured in July 1995 during the summer when this semi-anaerobic basin becomes chemically stratified. The OATZ occurs from about 3.3 to $3.7 \mathrm{~m}$. Magnetite $\left(\mathrm{Fe}_{3} \mathrm{O}_{4}\right)$-producing magnetotactic bacteria were found at the OATZ in samples collected from 3.0 to $3.7 \mathrm{~m}$. Greigite $\left(\mathrm{Fe}_{3} \mathrm{~S}_{4}\right)$-producing types were found below the OATZ in the anaerobic sulfidic zone from 3.7 $\mathrm{m}$ and below. The distribution of magnetotactic protists is shown in Table 1 with depths relating to this figure.

species. More elaborate techniques are required for positive identification to the species level including scanning electron microscopy and are beyond the scope of this paper. All four protistan types were found every summer under similar conditions in Salt Pond dating from 1994 to 1997 without significant depth differences relative to the OATZ.

Cells of biflagellate " $b$ " often contained large, dark-orange inclusions, mostly ranging from about 3.5 to $4.6 \mu \mathrm{m}$, usually at the end of the cell where the flagella were inserted (Fig. 2B). Cells were observed to occasionally extrude these inclusions into the surrounding fluid without apparent harm to the cells. When free in the fluid, the inclusions oriented in the applied magnetic field and rotated when the field direction was reversed. Following extrusion, cells of biflagellate " $b$ " were no longer responsive to the magnetic field.

\subsection{Behavior of magnetotactic protists}

The effect of a magnetic field on the motility of two protists, dinoflagellate " $a$ " and biflagellate " $b$ ", is shown in Fig. 3. Fig. 3A shows the edge of a droplet of water containing the magnetotactic protists $a$ and $b$ without an external magnetic field present. Fig. 3B-D show the effect of changing the orientation of the applied magnetic field (indicated by the arrow under the letter in the upper left hand corner of each panel) on the cells. Additional reversals of the direction of the magnetic field continued the pattern shown in Fig. 3B-D (data not shown). This 


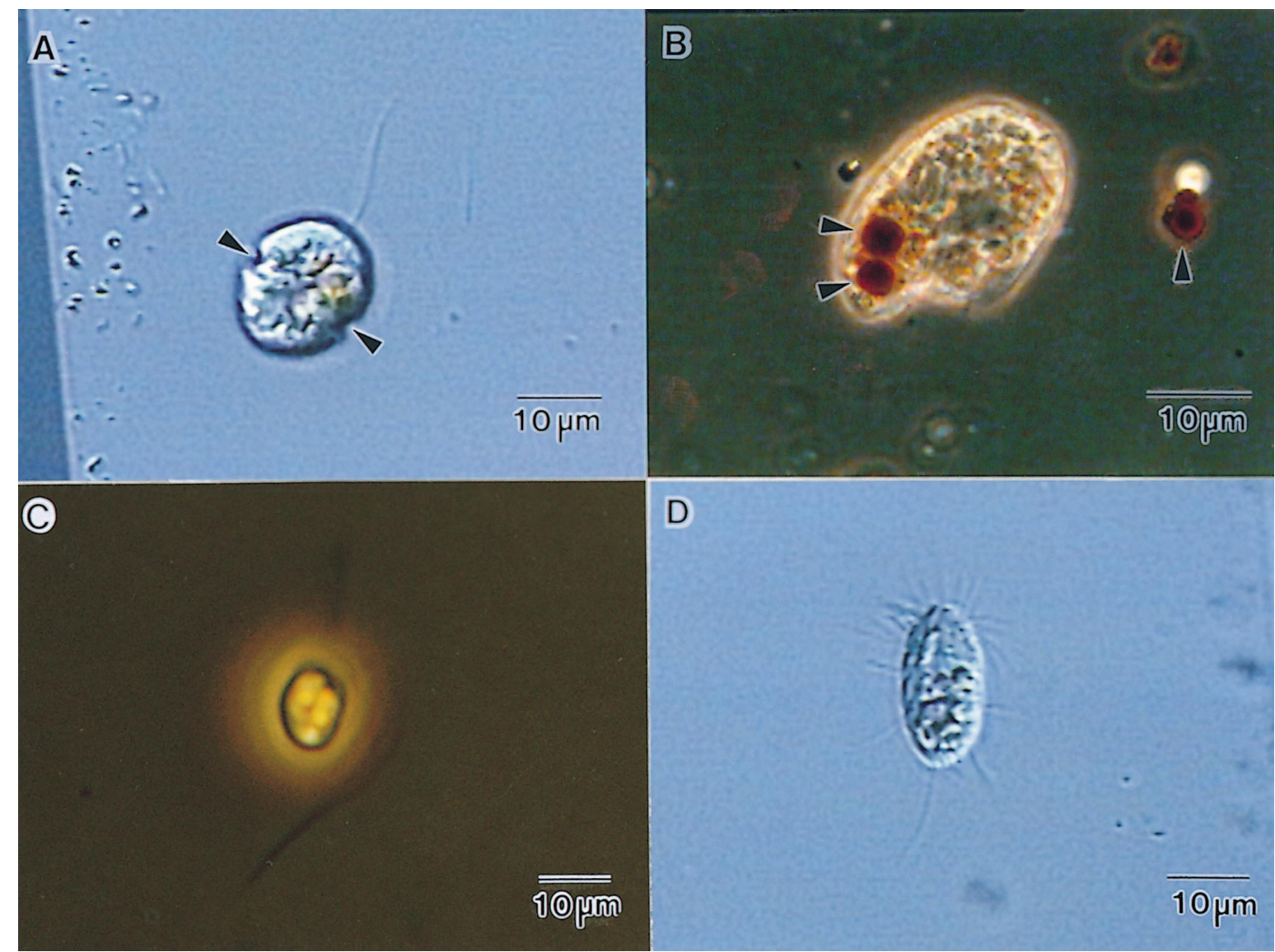

Fig. 2. Light micrographs of four types of magnetotactic protozoa. (A) Differential interference contrast (DIC) micrograph of dinoflagellate "a"; the girdle or annulus surrounding the test, typical of the dinoflagellate group, is apparent and is shown at the arrows. Note that one flagellum has broken off. (B) Phase contrast (PC) micrograph of biflagellate " $b$ "; note that neither flagella is visible and the presence of dark, spherical structures (at arrows) inside the cell. These structures can be extruded from the cell (arrow at right) and orient with the magnetic field. (C) PC micrograph of biflagellate " c"'; the two flagella are clearly evident on this cell. (D) DIC micrograph of ciliate " $d$ "; cilia are clearly evident.

Table 1

Magnetotactic protists present in Salt Pond

\begin{tabular}{lllll}
\hline Organism designation & Protistan type & Tentative identification & Size & Depth distribution $^{\text {a }}(\mathrm{m})$ \\
\hline a & Dinoflagellate & Dinoflagellate & $\sim 12.5-17-\mu \mathrm{m}$ long & $3.3-3.6 \mathrm{~m}$ \\
b & Biflagellate & Cryptomonad & $\sim 11-13-\mu \mathrm{m}$ wide & $3.5-3.7 \mathrm{~m}$ \\
& & & $\sim 26-28-\mu \mathrm{m}$ long & \\
c & Biflagellate & Cryptomonad & $\sim 12.5-15-\mu \mathrm{m}$ wide & $3.7-4.1 \mathrm{~m}$ \\
d & Ciliate & Cyclidium $\mathrm{sp}$. & $\sim 7.5-9-\mu \mathrm{m}$ wide & $3.8-3.9 \mathrm{~m}$ \\
& & & $\sim 20-22-\mu \mathrm{m}$ long & \\
\hline
\end{tabular}

${ }^{a}$ Depths at which organisms were observed in Salt Pond on 14 July, 1995. 

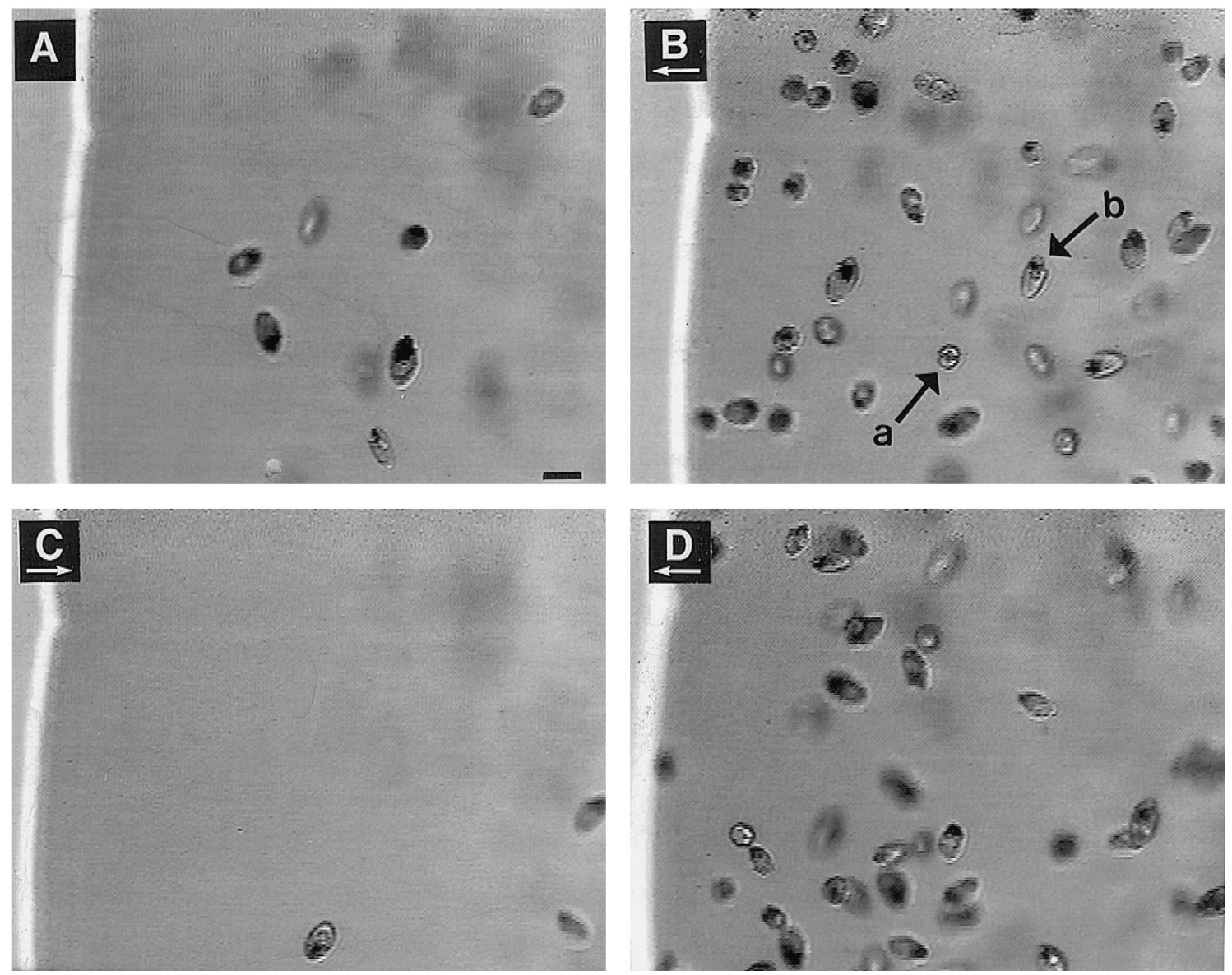

Fig. 3. The effect of a magnetic field on the behavior of two protists, a dinoflagellate " $a$ " and biflagellate " $b$ ", respectively, in the upper right panel. The microscope was focused on a point at the edge of the water drop closest to one pole of the bar magnet. A shows the organisms in that region before the magnet was placed on the stage. B shows the effect of the magnet with the south pole closest to the drop, producing a local field direction indicated by the arrow in the upper left corner. $\mathrm{C}$ shows the effect of reversing the bar magnet so that the north magnetic pole is closest to the edge of the drop. D shows the reversal of the magnet again, with the same orientation as in B. Images were taken approximately $45-60 \mathrm{~s}$ after the field was reversed. Bar in panel A represents $20 \mu \mathrm{m}$.

result demonstrates that the migration direction of these protistan cells is correlated with the orientation of the magnetic field. However, unlike the magnetotactic bacteria, biflagellate " $b$ " did not migrate directly along the magnetic field lines, rather it moved with frequent, spontaneous changes in direction only gradually migrating along magnetic field lines. This observation could mean that each cell has a permanent magnetic dipole moment as in the magnetotactic bacteria. This finding suggests that magnetotaxis is one of several tactic responses that determines the migration direction of this protist. Alternatively, cells of biflagellate " $b$ " could be following the magnetotactic bacteria in the water sample whose presence at the edge of the drop depends on the magnetic field orientation. Other magnetotactic protists showed a similar response.

In contrast, dinoflagellate " $a$ " and biflagellate " c" were observed to more directly migrate along magnetic field lines and to respond to a reversal of the magnetic field by rotating $180^{\circ}$ and continuing to swim in the same direction relative to the field direction. Evidence for a permanent magnetic dipole moment was also obtained for all magnetotactic pro- 
tists described above including the ciliate " $d$ ", by observing that non-swimming cells in suspension reoriented in response to a reversal of the local magnetic field. This effect is also typical of nonmotile (i.e., dead) magnetotactic bacteria in suspension.
3.4. Electron microscopy, energy dispersive X-ray analysis, electron diffraction

Most of the protistan types that were robust enough to be placed on electron microscopy grids without lysing contained chains of structures resem-

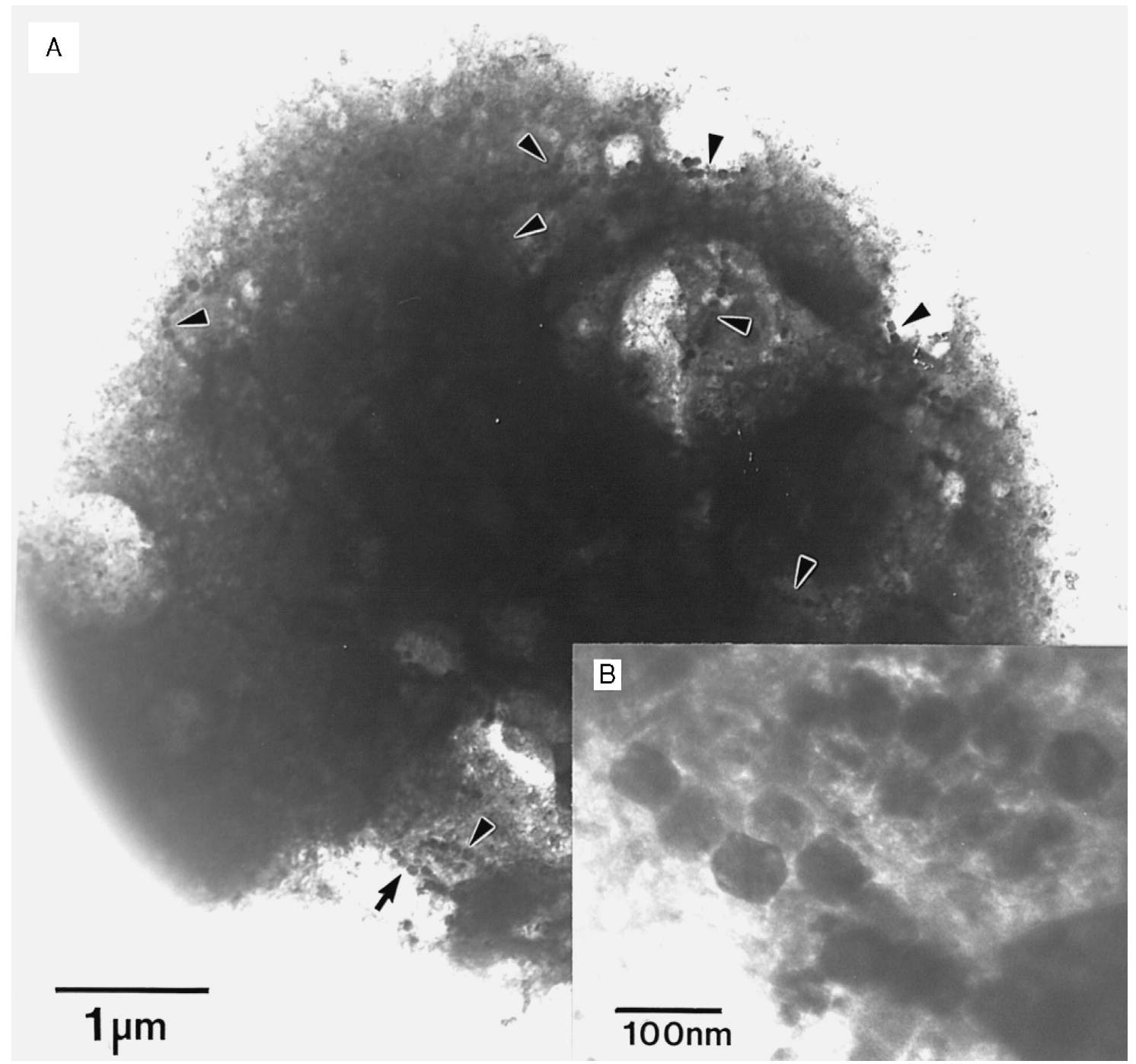

Fig. 4. (A) Low magnification transmission electron micrograph (TEM) of dinoflagellate " $a$ " showing numerous chains of magnetosome-like structures throughout the cell (at arrows). Because of the difficulty finding the particles in such a thick cell, a very high beam voltage was used which destroyed much of the cellular structure of the organism. (B) (inset) High magnfication TEM of magnetosome-like structures at long arrow in A. 
bling procaryotic magnetosomes (Fig. 4). Particles had similar morphologies and dimensions, about 55 to $75 \mathrm{~nm}$ in diameter, to those observed in the several magnetite-producing magnetotactic bacterial types also present on those same grids. Particles in biflagellate " $b$ " are shown in Fig. 5, together with iron, oxygen and sulfur elemental maps of those same particles. Particles consisted of iron and oxygen consistent with magnetite. Similar results were found for dinoflagellate ' $a$ '. Confirmation of magnetite was provided by electron diffraction patterns of individual particles in biflagellates " $b$ " and " $c$ ", (data not shown). Precise magnetite crystal morphologies were impossible to determine since we could not tell at which angle we were observing the particles in such thick cells. Greigite was identified as the mineral component in a number of procaryotic cells collected from the anaerobic sulfidic zone of Salt Pond but was not found in any protistan type examined in this study.
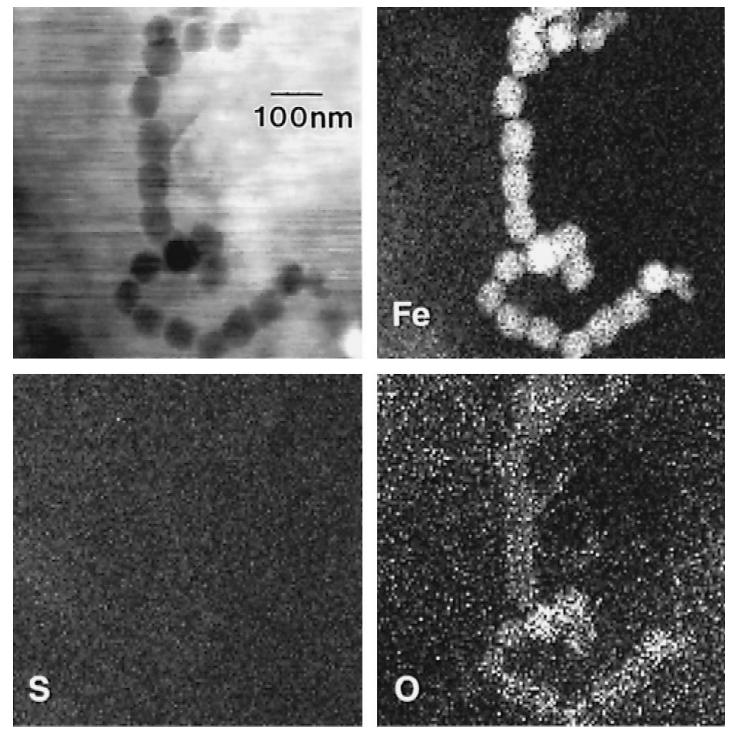

Fig. 5. Scanning transmission electron micrograph (top left) and $\mathrm{Fe}, \mathrm{S}$ and $\mathrm{O}$ elemental maps derived from energy dispersive X-ray analyses of a chain of magnetic particles in a cell of biflagellate " $b$ ". Note that Fe and $\mathrm{O}$ signals correlate with particle position while $\mathrm{S}$ does not. Results are consistent with the mineral magnetite $\left(\mathrm{Fe}_{3} \mathrm{O}_{4}\right)$.

\section{Discussion}

The results presented here clearly show that stable populations of diverse magnetic protists establish themselves at least on a yearly basis during the summer months when Salt Pond becomes chemically stratified. Because there is only a single report of magnetotaxis and magnetic particles occurring in a eucaryotic single-celled microorganism, a Euglenoid alga (Torres de Araujo et al., 1985), the findings presented here are significant in that they extend the occurrence of magnetism to a much wider range of single-celled protistan microorganisms.

However, the origin of the magnetosome-like structures within the protists described here is unknown. Two possibilities must be considered. First, the protists may be consuming magnetotactic bacteria and incorporating the cells and/or magnetosomes within themselves. As noted above, biflagellate " $b$ ", appears to have large, dark-orange, spherical inclusions within the cells that are occasionally extruded from the cell. The extruded inclusions reorient in response to reversals of the magnetic field while the protistan cell no longer shows a magnetic response. Although none of the magnetic protistan cells were ever observed to be engulfing magnetotactic bacteria, which are abundant at the same depths and clearly present in the water droplets we examined, it is possible, and perhaps likely, that these inclusions represent indigestable or partially digestible material including magnetosomes from ingested bacteria in vacuoles. On the other hand, the other protists we examined, including "a", "c" and "d", did not appear to possess such inclusions. Neither were structures resembling endosymbiotic bacteria ever observed within any of the protists. Interestingly, some protozoa are known to ingest iron filings and can then be attracted to a magnet (T. Fenchel, personal communication).

The second possibility is that some protists biomineralize endogenous magnetic particles. The fact that some protists such as "a" and "c" appear to contain magnetite particles of consistent size and uniform morphology, possess a permanent magnetic dipole moment and clearly show a directional preference (north-seeking in the Northern Hemisphere as in the magnetotactic bacteria, Frankel and Blakemore, 1980) supports this possibility. 
Magnetotaxis in magnetite-producing magnetotactic bacteria is thought to function with aerotaxis as an efficient means for cells to find and maintain an optimal position in vertical chemical and redox gradients in sediments and water columns (Frankel et al., 1997). For most magnetite-producing magnetotactic bacteria, the optimal position is at the OATZ. The question is whether magnetotaxis could function similarly in protistan species. Many types of protists appear to be microaerophilic and are known to be distributed to the OATZ (Fenchel, 1969; Fenchel and Finlay, 1984; Fenchel et al., 1989). Some are reported to use a geotactic mechanism that involves mineral mechanoreceptors and aerotaxis to find and maintain an optimal position in vertical oxygen concentration gradients (Fenchel and Finlay, 1984). Cells of Loxodes and another ciliate, Remenella, contain a unique organelle, referred to as the Müller body, thought to act as the mechanoreceptor for geotaxis. This structure appears to be a biomineralized concretion containing barium in Loxodes (Finlay et al., 1983) and strontium in Remanella (Rieder et al., 1982). Some of the protists described here could conceivably use magnetotaxis in place of geotaxis to find and maintain an optimal position in vertical concentration gradients as in the magnetotactic bacteria (Frankel et al., 1997).

Regardless of the origin and the function of the iron-containing magnetic particles in the magnetic protozoans described here, these organisms must contain a significant amount of intracellular iron and may play an important role in iron cycling in these aquatic habitats. Iron is well-recognized as a limiting factor in primary production in some oceanic areas and is often present in seawater in particulate and colloidal forms (Barbeau et al., 1996). Barbeau et al. (1996) have shown that digestion of colloidal iron in the food vacuoles of protozoans during grazing of particulate and colloidal matter might generate more bioavailable iron for other species, in this case, phyoplankton. In the case of Salt Pond, protists that ingest magnetotactic bacteria may play an important role in iron cycling by solubilizing iron in magnetosomes, which would likely contribute to the high ferrous iron concentration at the OATZ and the high microbial concentrations there. Interestingly, protozoans that biomineralize magnetic particles, like the magnetotactic bacteria, may tie up iron in the form of magnetosomes thereby making a significant amount of iron unavailable for organisms. If this is the case, then these organisms, also like the magnetotactic bacteria, might directly contribute to the magnetization of sediments. It is clear that a more detailed examination of these protists, as well as pure culture studies, are required to elucidate the role of these organisms in iron cycling and in the biomineralization of iron mineral species.

Finally, there is also a question of whether magnetic protists occur in other chemically stratified aquatic environments. We have reviewed numerous video tapes of magnetic microorganisms in water samples collected in the past from the OATZ of the Pettaquamscutt Estuary (Narragansett, RI, USA), a site similar to that of Salt Pond except that it is stratified all year (Donaghay et al., 1992; Bazylinski et al., 1995). Magnetically responsive protistan cells resembling biflagellate " $c$ " were present in several samples collected from specific depths from this site. In addition, we have found magnetic Gymnodinioid dinoflagellates in samples collected from salt marsh pools at the Ebro Delta, Spain. We conclude that magnetic protists are easily overlooked in the presence of high numbers of magnetotactic bacteria particularly when they are large in size and that these organisms may represent a previously undescribed, important microbiological component common to chemically stratified aquatic habitats. More detailed ecological studies are warranted to confirm this possibility.

\section{Acknowledgements}

We thank E.R. Leadbetter for use of the Marine Biological Laboratory (Woods Hole, MA, USA) Microbial Ecology Course facilities; T. Pitta for help with optical and electron microscopy; the late H.W. Jannasch who generously let us use his laboratory year after year during our Salt Pond studies; C.O. Wirsen and D. Goehringer, whose technical expertise and willingness to help is unsurpassed; T. Fenchel and H. Dong for their helpful reviews, suggestions, and help with identification of protists; R. Guerrero for his invitation to visit the Ebro Delta; and J.M. Kenton for help preparing figures. This work was supported by U.S. Office of Naval Research grant 
ONR N00014-91-J-1290 (RBF and DAB) and U.S. National Science Foundation grants MCB-9696027 (DAB) and CHE-9714101 (RBF and DAB).

\section{References}

Balkwill, D.L., Maratea, D., Blakemore, R.P., 1980. Ultrastructure of a magnetic spirillum. J. Bacteriol. 141, 1399-1408.

Barbeau, K., Moffett, J.W., Caron, D.A., Croot, P.L., Erdner, D.L., 1996. Role of protozoan grazing in relieving iron limitation of phytoplankton. Nature 380, 61-64.

Bazylinski, D.A., Moskowitz, B.M., 1997. Microbial biomineralization of magnetic iron minerals: microbiology, magnetism and environmental significance. Geomicrobiology: Interactions Between Microbes and Minerals. In: Banfield, J.F., Nealson, K.H. (Eds.), Rev. Mineral. vol. 35 Mineralogical Society of America, Washington, DC, pp. 181-223.

Bazylinski, D.A., Garratt-Reed, A.J., Frankel, R.B., 1994. Electron microscopic studies of magnetosomes in magnetotactic bacteria. Microsc. Res. Tech. 27, 389-401.

Bazylinski, D.A., Frankel, R.B., Heywood, B.R., Mann, S., King, J.W., Donaghay, P.L., Hanson, A.K., 1995. Controlled biomineralization of magnetite $\left(\mathrm{Fe}_{3} \mathrm{O}_{4}\right)$ and greigite $\left(\mathrm{Fe}_{3} \mathrm{~S}_{4}\right)$ in a magnetotactic bacterium. Appl. Environ. Microbiol. 61, 3232-3239.

Blakemore, R.P., 1975. Magnetotactic bacteria. Science 190, 377379.

Cline, J.D., 1969. Spectrophotometric determination of hydrogen sulfide in natural waters. Limnol. Oceanogr. 14, 454-458.

Donaghay, P.L., Rines, H.M., Sieburth, J.M., 1992. Simultaneous sampling of fine scale biological, chemical and physical structure in stratified waters. Arch. Hydrobiol., Beih. Ergeb. Limnol. 36, 97-108.

Fenchel, T., 1969. The ecology of marine microbenthos: IV.
Structure and function of the benthic ecosystem, its chemical and physical factors and the microfauna communities with special reference to the ciliated protozoa. Ophelia 6, 1-182.

Fenchel, T., Finlay, B.J., 1984. Geotaxis in the ciliated protozoan, Loxodes. J. Exp. Biol. 110, 17-33.

Fenchel, T., Finlay, B.J., Gianni, A., 1989. Microaerophily in cilates: responses of an Euplotes species (Hypotrichida) to oxygen tension. Arch. Protistenkd. 137, 317-330.

Finlay, B.J., Hetherington, N.B., Davison, W., 1983. Active biological participation in lacustrine barium chemistry. Geochim. Cosmochim. Acta 47, 1325-1329.

Frankel, R.B., Blakemore, R.P., 1980. Navigational compass in magnetic bacteria. J. Magn. Magn. Mater. 15-18, 1562-1564.

Frankel, R.B., Bazylinski, D.A., Johnson, M., Taylor, B.L., 1997. Magneto-aerotaxis in marine, coccoid bacteria. Biophys. J. 73, 994-1000.

Kobayashi, A., Kirschvink, J.L., 1995. Magnetoreception and electromagnetic field effects: sensory perception of the geomagnetic field in animals and humans. In: Blank, M. (Ed.), Electromagnetic Fields: Biological Interactions and Mechanisms. American Chemical Society, Washington, DC, pp. 367-394.

Lovley, D.R., Phillips, E.J.P., 1987. Rapid assay for microbially reducible ferric iron in aquatic sediments. Appl. Environ. Microbiol. 52, 751-757.

Rieder, N., Ott, H.A., Pfundstein, P., Schoch, R., 1982. X-ray microanalysis of the mineral contents of some protozoa. J. Protozool. 29, 15-18.

Torres de Araujo, F.F., Pires, M.A., Frankel, R.B., Bicudo, C.E.M., 1985. Magnetite and magnetotaxis in algae. Biophys. J. 50, 375-378.

Wakeham, S.G., Howes, B.L., Dacey, J.W.H., 1984. Dimethyl sulphide in a stratified coastal salt pond. Nature 310, 770-772.

Wakeham, S.G., Howes, B.L., Dacey, J.W.H., Schwarzenbach, R.P., Zeyer, J., 1987. Biogeochemistry of dimethylsulfide in a seasonally stratified coastal salt pond. Geochim. Cosmochim. Acta 51, 1675-1684. 